\title{
Chemostat Production of Plantaricin C By Lactobacillus plantarum LL441
}

\author{
J. M. BRUNO BÁRCENA,${ }^{1} \dagger$ F. SIÑERIZ,${ }^{1} \ddagger$ D. GONZÁLEZ DE LLANO,${ }^{1}$ ANA RODRÍGUEZ,${ }^{1}$ \\ AND JUAN E. SUÁREZ ${ }^{1,2 *}$ \\ Instituto de Productos Lácteos de Asturias (IPLA-CSIC), 33300 Villaviciosa, Asturias, ${ }^{1}$ and Área de Microbiología, \\ Facultad de Medicina, Universidad de Oviedo, 33006 Oviedo, ${ }^{2}$ Spain
}

Received 7 November 1997/Accepted 5 July 1998

\begin{abstract}
Plantaricin C, a bacteriocin synthesized by Lactobacillus plantarum LL441, was optimally produced in chemostats kept at $\mathrm{pH} 5.0,30^{\circ} \mathrm{C}, 150 \mathrm{rpm}$, and a dilution rate of $0.05 \mathrm{~h}^{-1}$ when glucose was used as carbon source and a dilution rate of 0.10 to $0.12 \mathrm{~h}^{-1}$ when sucrose or fructose was used instead. Production was abolished at high dilution rates, i.e., when the cells grew rapidly in all carbon sources.
\end{abstract}

During a screening for bacteria with good technological properties, Lactobacillus plantarum LL441 was isolated from homemade cheese whey. It produces one bacteriocin, plantaricin $\mathrm{C}(6)$, a $3.5-\mathrm{kDa}$ peptide that is resistant to harsh environmental conditions and active at $\mathrm{pH}$ values from 2.0 to 7.0. It is bactericidal, and in some cases bacteriolytic, to a range of gram-positive organisms that include members of the genera Clostridium, Bacillus, and Staphylococcus and also to Listeria monocytogenes (6). Plantaricin $\mathrm{C}$ induces the formation of pores in the plasma membrane of sensitive cells, resulting in the dissipation of the proton motive force and in leakage of cytoplasmic solutes. No receptor or energized membranes are needed for its action, explaining, in part, its wide range of susceptible bacteria (7). All these properties allow plantaricin $\mathrm{C}$ to be considered a potential food preservative. To achieve this objective, one of the first requirements is mass production of the bacteriocin under standardized conditions to ensure a regular supply for the different tests to be performed and, eventually, for the market. We chose continuous culture as a first step towards this goal.

L. plantarum LL441 was grown in MRS (4) broth to stationary phase, concentrated 10 -fold in fresh MRS containing $20 \%$ (vol/vol) glycerol, and stored at $-20^{\circ} \mathrm{C}$. Aliquots $(15 \mathrm{ml}$ each) of this culture were used every time the fermentor was inoculated. Unless otherwise stated, the culture medium (BRFS) contained (in grams per liter) yeast extract, $10 ; \mathrm{MgSO}_{4} \cdot 7 \mathrm{H}_{2} \mathrm{O}$, 0.05; $\left(\mathrm{NH}_{4}\right)_{2} \mathrm{HPO}_{4}, 2.5 ; \mathrm{MnSO}_{4}, 0.005$; and the carbon source (glucose, sucrose, or fructose), 5. In experiments during medium development, the growth rate increased up to sugar concentrations of $20 \mathrm{~g} /$ liter (higher concentrations were not tested), indicating that it was unlikely that other medium components would be limiting when the carbon source was used at $5 \mathrm{~g} /$ liter. Incubation was done in a chemostat Biostat B (Braun, Melsungen, Germany) at $30^{\circ} \mathrm{C}$, with a working volume of $700 \mathrm{ml}$. The $\mathrm{pH}$ was maintained by the automatic addition of $2 \mathrm{~N} \mathrm{NH}_{4} \mathrm{OH}$. The cultures were stirred at $150 \mathrm{rpm}$. Cultures

\footnotetext{
* Corresponding author. Mailing address: Área de Microbiología, Facultad de Medicina, Universidad de Oviedo, c/ Julián Clavería s/n, 33006 Oviedo, Spain. Phone: 34851035 59. Fax: 3485103148. E-mail: jsuarez@sauron.quimica.uniovi.es.

$\dagger$ Present address: PROIMI, 4000 San Miguel de Tucumán, Argentina.

$\ddagger$ Present address: PROIMI and Cátedra de Microbiología Superior, Facultad de Bioquímica, Química y Farmacia, Universidad Nacional de Tucumán, 4000 San Miguel de Tucumán, Argentina.
}

were started in batch mode. When the population in the vessel reached the exponential phase, continuous cultures were established by pumping in fresh medium, starting at the lowest dilution rate. Steady-state growth, as assessed by biomass, and glucose and lactate concentrations, was reached after three to four residence times of fresh medium passed through the chemostat. Steady-state conditions were maintained for at least two more volume passages, and only afterwards was data collection started. All values shown in the text are averages of triplicates that differed by less than $5 \%$. The dilution rates could be varied upwards or downwards, resulting in constant product concentrations once steady states were reestablished.

Biomass was measured as the absorbance at $600 \mathrm{~nm}\left(A_{600}\right)$. Dry-weight determinations were carried out after triplicate culture samples $(3 \mathrm{ml}$ each) were passed through $0.22-\mu \mathrm{m}$ pore-size filters and dried at $85^{\circ} \mathrm{C}$ overnight. A correlation between dry weight and $A_{600}$ was established to calculate the biomass concentration from the absorbance readings.

Plantaricin $\mathrm{C}$ production was tested by the agar well diffusion test (17), with Lactobacillus sake CECT 906 as the indicator strain. The titer was defined as the reciprocal of the highest dilution showing definite inhibition of growth of the indicator lawn and was expressed in arbitrary activity units per milliliter.

Glucose level was determined with the glucose (Trinder) kit (Sigma Chemical Co., St. Louis, Mo.). Other sugars, lactate, acetate, and formate were determined by high-pressure liquid chromatography with a Beckman System Gold Liquid Chromatograph as previously described (8).

Influence of $\mathbf{p H}$ on the production of plantaricin $\mathrm{C}$. To establish the optimal $\mathrm{pH}$ value for plantaricin $\mathrm{C}$ production, a chemostat was run at a dilution rate of $0.15 \mathrm{~h}^{-1}$, which corresponds to about $20 \%$ of the maximal growth rate. The growthlimiting substrate, glucose, was fed at a concentration of 5 $\mathrm{g} /$ liter at time zero. The production of plantaricin $\mathrm{C}$ was evaluated in steady state at $\mathrm{pH}$ values of 4.5, 5.0, 5.5, and 6.0. Plantaricin C was detected only at $\mathrm{pH}$ 5.0. The $\mathrm{pH}$ seems to be a factor that affects bacteriocin production by lactic acid bacteria $(3,5,13,14)$, possibly indicating that it has a regulatory effect driven by the ionic conditions of the medium or that it may exert a general effect on the cell envelope, since variations in the osmolarity of the media (18) or in the concentrations of ethanol (13) and Tween 80 (15) were shown to influence the levels of production of other bacteriocins.

Growth of $L$. plantarum LL441 in the chemostat. In order to determine the maximum productivity of the strain, steady 


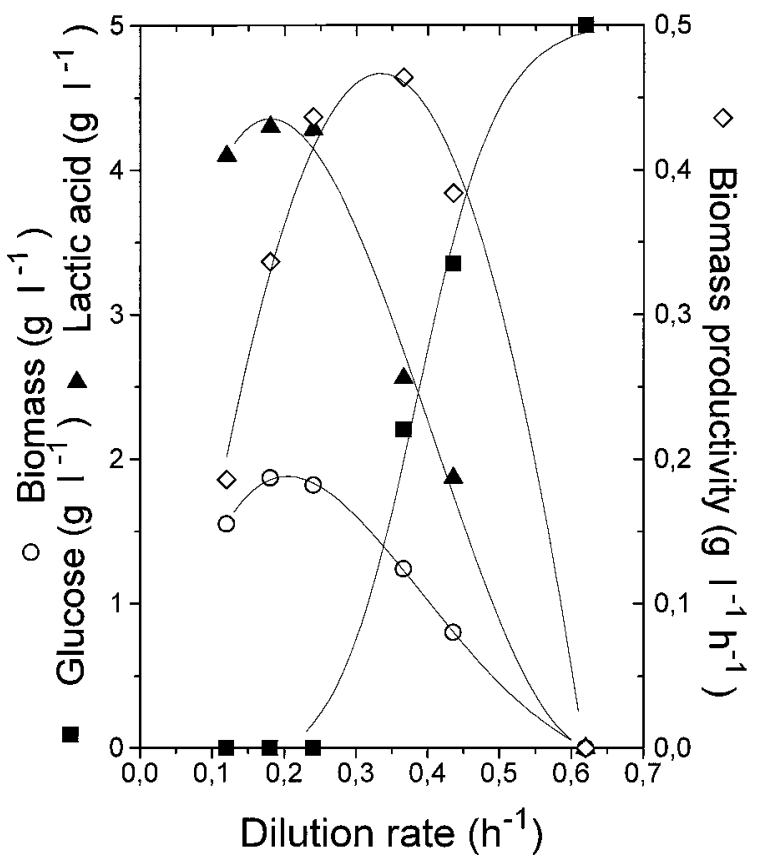

FIG. 1. Effects of the dilution rate on biomass, glucose, and lactic acid concentrations, and biomass productivity by L. plantarum LL441 grown in BRFS medium with $0.5 \%$ glucose at $30^{\circ} \mathrm{C}$, a pH of 5.0 , and $150 \mathrm{rpm}$.

states were obtained at different dilution rates, with glucose as the carbon source and the $\mathrm{pH}$ kept at 5.0 (Fig. 1). Calculation of the critical dilution rate $\left(0.62 \mathrm{~h}^{-1}\right)$ corresponding to the maximal growth rate was done by the method of Pirt and Callow (16). Maximum biomass productivity (0.47 g [dry weight] liter ${ }^{-1} \mathrm{~h}^{-1}$ ) corresponded to a dilution rate of 0.33 $\mathrm{h}^{-1}$, around $50 \%$ of the maximal growth rate $\left(\mu_{\max }=0.62\right.$ $\left.\mathrm{h}^{-1}\right)$. This behavior seems to be characteristic of lactobacilli (1, 9, 10). Lactate was the only fermentation product that was detected among those we looked for (lactate, acetate, and formate), and the fermentation balances were close to $100 \%$ carbon recovery (data not shown).

Influence of the dilution rate and carbon source on the production of plantaricin C. Plantaricin $\mathrm{C}$ production was tested at different dilution rates, with glucose, sucrose, or fructose as a growth-limiting substrate; all were fed at the time zero concentration of $0.5 \%$ (wt/vol).

The synthesis of plantaricin $\mathrm{C}$, with glucose as the carbon source, is shown in Fig. 2a. Production occurred only at very low dilution rates $\left(0.05 \mathrm{~h}^{-1}\right)$, when the bacteria were growing very slowly. This finding is in agreement with a previous observation (6) in which plantaricin $C$ was produced at the end of the exponential growth phase in MRS broth when, presumably, the substrate levels were declining, which in turn would provoke a decrease in the growth rate of the cultures. Generally, it is assumed that bacteriocins are produced during the exponential growth phase; hence, their synthesis would be considered growth linked $(5,14)$. If this was true, production would have resulted in a line parallel to biomass concentration and productivity would be maximal near the $\mu_{\max }$. However, plantaricin $\mathrm{C}$ production was observed only at very low dilution rates, i.e., when the cultures grew slowly; consequently, production would probably be best considered to be typical of a product synthesized during the exponential/stationary growth transition phase, as was already anticipated by batch experiments (see above). This situation might be more general; for

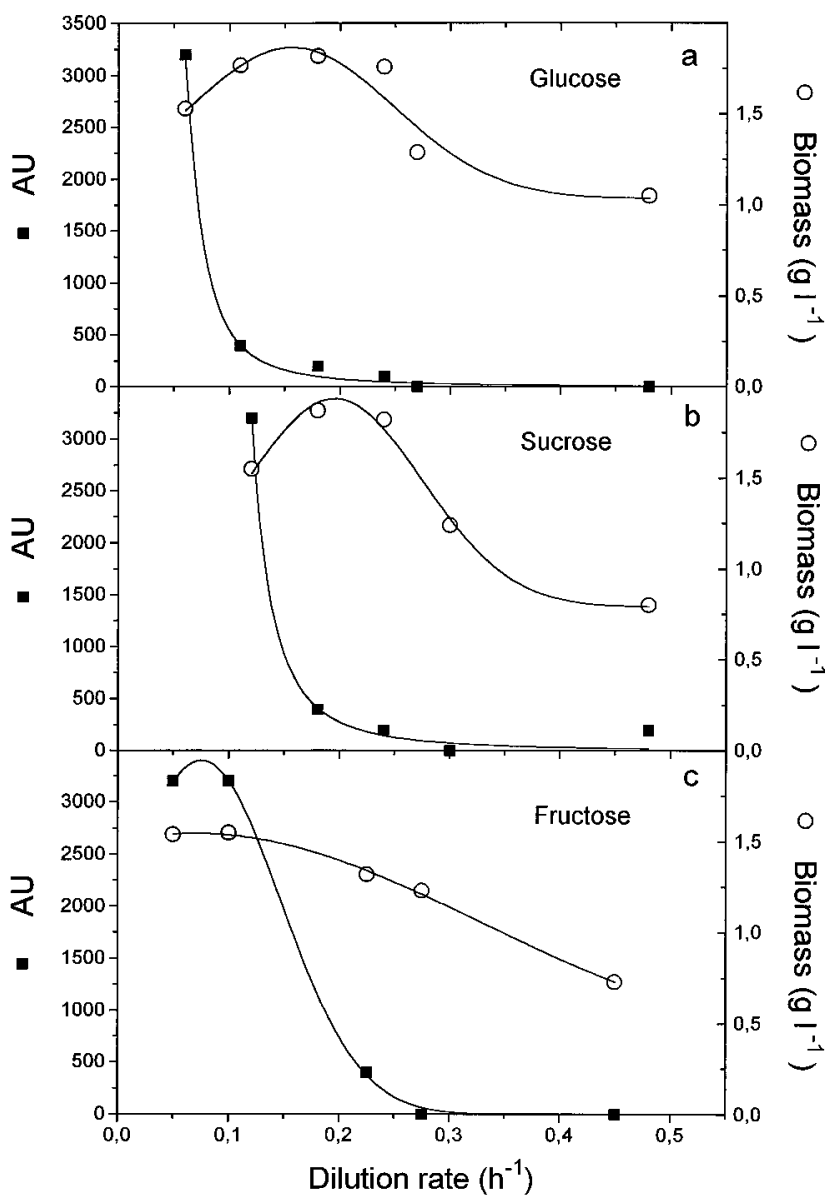

FIG. 2. Effects of the dilution rate on biomass concentration and plantaricin $\mathrm{C}$ production (arbitrary activity units) by L. plantarum LL441 grown in BRFS medium with $0.5 \%$ of different carbon sources at $30^{\circ} \mathrm{C}$, a pH of 5.0 , and $150 \mathrm{rpm}$. AU, arbitrary units.

example, de Vuyst and Vandamme (5) found that there is a lag in nisin production with respect to growth in cultures of $\mathrm{Lac}$ tococcus lactis incubated with sucrose as a carbon source. Furthermore, the production of pediocin $\mathrm{AcH}$ by Pediococcus acidilactici $\mathrm{H}$ (3) might follow secondary metabolite kinetics although, as the $\mathrm{pH}$ was not controlled, the data might be misleading, since $\mathrm{pH}$ presumably influences production of the bacteriocin. On the other hand, production of lactococcin 140 by $L$. lactis seems to be growth linked (14).

Since glucose may act as a mediator of catabolic repression, the influence of other carbon sources was tested. Experiments were carried out with sucrose (Fig. 2b) or fructose (Fig. 2c). In these cases production of plantaricin $\mathrm{C}$ was found at dilution rates $\left(0.1\right.$ to $\left.0.12 \mathrm{~h}^{-1}\right)$ double those determined to give significant production with glucose, although further increases in the dilution rate resulted in the abolition of bacteriocin synthesis. It was also determined that the bacteriocin titers of the culture supernatants were similar under optimal conditions for the three carbon sources tested, i.e., the yield was doubled in media with sucrose or fructose with respect to glucose. The apparent difference between plantaricin $\mathrm{C}$ production in media with glucose, sucrose, and fructose was confirmed by analysis of variance (12), which showed significant differences $(P<$ $0.01)$. However, no significant differences were found between the production levels of these last two sugars. 
All homofermentative lactic acid bacteria examined so far possess phosphoenolpyruvate-sugar phosphotransferase systems (2) and, consequently, glucose would inhibit the uptake of sugars via phosphorylation of the heat-stable protein of the phosphoenolpyruvate-sugar phosphotransferase systems system (19). The availability of glucose increases with dilution rate, which could lead to increased levels of phosphorylated products which may trigger regulatory mechanisms, leading to a reduced glucose intake and to the switching off of catabolitesensitive operons. This may be the case of plantaricin $\mathrm{C}$, because media with sucrose or fructose as carbon sources still supported its synthesis at concentrations that did not allow synthesis when the sugar used was glucose.

From the point of view of the producer strain, the synthesis of antimicrobial substances would be advantageous precisely when nutrients become limiting, because under these conditions, the bacteriocins produced would antagonize potential competitors for the exhausting nutrients, a concept discussed in early reviews on antibiotic production (11). This situation reflects what occurs in chemostats at low dilution rates, when ATP levels in the cell are low and the regulatory mechanisms mediated by phosphorylated proteins would not be activated.

Finally, the supernatant of the harvest bottle (collected in the cold for $24 \mathrm{~h}$ ) had the same titer as the medium in the chemostat, indicating that downstream processing can be made batchwise at least every $24 \mathrm{~h}$.

The results presented here raise the possibility of scaling up plantaricin $\mathrm{C}$ production experiments to pilot plant assays. The starting conditions would probably be a batch-fed system with a limited carbon source, a controlled $\mathrm{pH}$, and feed rates corresponding to 10 to $20 \%$ of the $\mu_{\max }$.

This work was supported by grants ALI93-0873-CO2 and BIOT-CT960402 from the Comisión Interministerial de Ciencia y Tecnología of Spain and the BIOTECH Program of the European Union, respectively. F.S. was the recipient of a visitor's grant from the University of Oviedo. We thank the Consejo de Investigaciones de la Universidad Nacional de Tucumán (CIUNT) and UNESCO on its 50th anniversary.

\section{REFERENCES}

1. Aeschlimann, A., L. Di Stasi, and V. von Stockar. 1990. Continuous production of lactic acid from whey permeate by Lactobacillus helveticus in two chemostats in series. Enzyme Microb. Technol. 12:26-932.

2. Axelsson, L. T. 1993. Lactic acid bacteria: classification and physiology, p. 1-63. In S. Salminen and A. von Wright (ed.), Lactic acid bacteria. Marcel
Dekker, Inc., New York, N.Y.

3. Biswas, S. R., P. Ray, M. C. Johnson, and B. Ray. 1991. Influence of growth conditions on the production of a bacteriocin, pediocin $\mathrm{AcH}$, by Pediococcus acidilactici $\mathrm{H}$. Appl. Environ. Microbiol. 57:1265-1267.

4. de Man, J. C., M. Rogosa, and M. E. Sharpe. 1960. A medium for the cultivation of lactobacilli. J. Appl. Bacteriol. 23:30-135.

5. de Vuyst, L., and E. J. Vandamme. 1992. Influence of the carbon source on nisin production in Lactococcus lactis subsp. lactis batch fermentations. J. Gen. Microbiol. 138:571-578.

6. González, B., P. Arca, B. Mayo, and J. E. Suárez. 1994. Detection, purification and partial characterization of plantaricin $\mathrm{C}$, a bacteriocin produced by a Lactobacillus plantarum strain of dairy origin. Appl. Environ. Microbiol. 60:2158-2163.

7. González, B., E. Glaasker, R. S. Kunji, A. Driessen, J. E. Suárez, and W. Konings. 1996. Bactericidal mode of action of plantaricin C. Appl. Environ. Microbiol. 62:2701-2709.

8. González de Llano, D., A. Rodríguez, and P. Cuesta. 1996. Effect of lactic starter cultures on the organic acid composition of milk and cheese during ripening. Analysis by HPLC. J. Appl. Bacteriol. 80:570-576.

9. González-Vara, R. A., D. Pinelli, M. Rossi, D. Fajner, F. Magelli, and D. Matteuzzi. 1996. Production of $\mathrm{L}(+)$ and $\mathrm{D}(-)$ lactic acid isomers by Lactobacillus casei subsp. casei DSM 20011 and Lactobacillus coryneformis subsp. torquens DSM 20004 in continuous fermentation. J. Ferment. Bioeng. 81: 548-552.

10. Jarry, A. 1994. Production industrielle d'acide lactique, p. 519-525. In H. de Roissart and F. M. Luquet (ed.), Bacteries lactiques, vol. II. Lorica, Grenoble, France.

11. Martin, J. F., and A. L. Demain. 1980. Control of antibiotic biosynthesis. Microbiol. Rev. 44:230-251.

12. Miller, J. C., and J. N. Miller. 1988. Significance tests, p. 53-80. In R. A. Chalmers and M. Mason (ed.), Statistics for analytical chemistry. Ellis Horwood Limited, Chichester, England.

13. Mortvedt-Abildgaard, C. I., J. Nissen-Meyer, B. Jelle, B. Grenov, M. Skaugen, and I. F. Nes. 1995. Production and pH-dependent bactericidal activity of Lactocin S, a lantibiotic from Lactobacillus sake L45. Appl. Environ. Microbiol. 61:175-179.

14. Parente, E., A. Ricciardi, and G. Addario. 1994. Influence of $\mathrm{pH}$ on growth and bacteriocin production by Lactococcus lactis subsp. lactis $140 \mathrm{NWC}$ during batch fermentation. Appl. Environ. Biotechnol. 41:388-394.

15. Parente, E., and C. Hill. 1992. A comparison of the factors affecting the production of two bacteriocins from lactic acid bacteria. J. Appl. Bacteriol. 73:290-298.

16. Pirt, S. J., and D. S. Callow. 1960. Studies on the growth of Penicillium chrysogenum in continuous flow culture with reference to penicillin production. J. Appl. Bacteriol. 23:87-98.

17. Reddish, G. F. 1929. Methods for testing antiseptics. J. Lab. Clin. Med. 14:649-658.

18. Ruiz-Barba, J. L., D. P. Catchcart, P. J. Warner, and R. Jiménez-Diaz. 1994. Use of Lactobacillus plantarum LPCO10, a bacteriocin producer, as a starter culture in Spanish-style green olive fermentations. Appl. Environ. Microbiol. 60:2059-2064.

19. Saier, M. H., S. Chauvaux, G. M. Cook, J. Deutscher, I. T. Paulsen, J. Reizer, and J.-J. Ye. 1996. Catabolite repression and inducer control in Grampositive bacteria. Microbiology 142:217-230. 